\title{
Genetic structure of populations of several endangered and endemic Dianthus species revealed by microsatellite markers
}

\author{
Anca Butiuc-Keul ${ }^{1,2^{*}}$, Cornelia Crăciunaș ${ }^{1,2}$, Irina Goia ${ }^{3,2}$, Anca Farkas ${ }^{1,2}$, Liliana Jarda ${ }^{4}$, \\ Victoria Cristea ${ }^{4,2}$ \\ ${ }^{1}$ Department of Molecular Biology and Biotechnology, Faculty of Biology and Geology, Babeş-Bolyai University, 400084 \\ Cluj-Napoca, Romania \\ ${ }^{2}$ Laboratory of Plant Biology, Genetics, Microbiology and Biotechnology, Center of Systems Biology, Biodiversity and \\ Bioresources, Babeş-Bolyai University, 400006 Cluj-Napoca, Romania \\ ${ }^{3}$ Department of Taxonomy and Ecology, Faculty of Biology and Geology, Babeş-Bolyai University, 400015 Cluj-Napoca, \\ Romania \\ ${ }^{4}$ Alexandru Borza Botanical Garden, Babeş-Bolyai University, 400015 Cluj-Napoca, Romania
}

\begin{abstract}
In order to develop a proper conservation programme for several endangered, rare or endemic species of Dianhtus from Romania, molecular characterization by simple sequence repeat (SSR) markers has been accomplished. Amplification of SSR loci in individuals belonging to different populations of D. callizonus, D. glacialis ssp. gelidus, D. henteri, D. nardiformis and D. tenuifolius revealed 23 polymorphic alleles. D. callizonus and D. tenuifolius showed particular sets of SSR alleles. D. glacialis ssp. gelidus, D. henteri and D. nardiformis proved to share almost the same alleles in most of the loci. The highest genetic diversity was observed in D. glacialis ssp. gelidus and D. tenuifolius in locus MS-DINMADSBOX. Allelic patterns across Dianthus species indicate that the mean number of different alleles was highest in D. glacialis ssp. gelidus, while the number of effective alleles was highest in $D$. tenuifolius. There are no particular differences in individuals belonging to the same species. Genetic diversity is generally low, ranging from 0.18 (D. callizonus) to 0.44 (D. henteri). Regarding the genetic diversity within populations of the same species, no differences were revealed by the use of the SSR markers tested in the present study.
\end{abstract}

Key words: Dianthus, endemic species, genetic structure, microsatellites, SSR markers, polymorphism

\section{Introduction}

In the last decades, habitat modifications induced by climate change and human activity led to the extinction of many plant species. Species conservation programs targeting large areas should focus on the most valuable populations and so require a better understanding of species biology and ecology as well as knowledge of the genetic diversity distribution within and among populations. Genetic diversity is important because it influences the populations' ability to adapt to a changing environment conditions. A characteristic of rare or endemic plants is the maintenance of low levels of genetic variation. Limited genetic diversity has been reported for many rare plant species (Hamrick et al. 1991, Frankham 1996, Leimu et al. 2006, Szczecińska et al. 2016).
The genetic diversity within an endangered population is lost due to relatively faster genetic drift, which is exacerbated by limited gene flow. This can lead to inbreeding depression and higher homozygosity, which results in reduced adaptive potential (Reed and Frankham 2003, Johansson et al. 2007). Genetic diversity is often correlated with plant fitness (Leimu et al. 2006, Ilves et al. 2013).

Genetic structure of plant populations, the level of genetic polymorphism within and among populations could offer information of value in the development of proper strategies for their conservation. The aim of conservation programs is to preserve the highest number of populations, as well as their genetic structure and variability. The genetic structure and variability of endemic and rare plant populations were

\footnotetext{
* Corresponding author, e-mail: anca.keul@ubbcluj.ro
} 
intensively studied by izoenzymes (Gitzendanner and Soltis 2000) and nuclear DNA markers (Pritchard et al. 2000, Cruzan 2001, Kang et al. 2005, ${ }^{\circ}$ Cuan et al. 2006, Breinholt el al. 2007). Among these markers, simple sequence repeats (SSR) are frequently used to investigate genetic structure and variability in plant populations because of their cost effectiveness (Zietkiewicz et al. 1994, Varshney et al. 2005). There are many previous data regarding the usefulness of SSR in genetic studies in rare and endangered plants (Katoh et al. 2007, Sosa et al. 2010). Molecular characterization of the carnation was previously reported by sequence-related amplified polymorphism (SRAP) and inter simple sequence repeat (ISSR) markers (Fu et al. 2008). SSR markers have been also used for genotyping of carnation varieties (Smulders et al. 2003).

Dianthus is one of the most diverse Mediterranean-type plant genera; more than 300 species are distributed throughout Eurasia and Africa. Over 100 species of Dianthus species occur in Europe, and more than 70 are endemic (Valente et al. 2010). In Romania, 58 Dianthus taxa have been recorded (Ciocârlan 2009), of which 8 are endemic. Recent works have analysed the genetic variability of two endemic and endangered species of Dianthus from Romania (D. spiculifolius Schur; D. giganteus d'Urv. subsp. banaticus (Heuff) (Cristea et al. 2014, Jarda et al. 2014, Gabel et al. 2017).

In this paper we investigate the genetic diversity of 5 endemic and threatened Romanian Dianthus species using SSR markers. D. callizonus Schott \& Kotschy, a Dacian element, is strictly endemic to the Curvature Carpathian Mountains. Previously classified as Vulnerable (VU) by Oprea (2005), it is currently considered as Low Risk (LR) species in the Red Book of Vascular Plants from Romania (Dihoru and Negrean 2009). D. callizonus grows on alpine and subalpine calcareous rocks. D. glacialis Haenke ssp. gelidus (Schott, Nyman \& Kotschy) Tutin is a taxon endemic to the Eastern and Southern Carpathians (Oprea 2005). It is sporadic in alpine communities on calcareous rocks. D. henteri Heuff. ex Griseb. \& Schenk is endemic to the Southern Carpathians. This species grows on rocky soils, in the beech and spruce belt (Sârbu et al. 2013). D. nardiformis Janka grows on rocky areas, in the Lower Danube Basin and in the Dobrudja region. This species is considered VU (Oprea 2005, Dihoru and Negrean 2009). D. tenuifolius Schur is an endemic species in the Romanian Carpathians and grows in meadows, on skeletal soil. It is considered a Least Concern (LC) species by Oprea (2005). All taxa are presumably diploids $(2 \mathrm{n}=30)$, according to Carolin (1957), a ploidy feature that may allow an easy interpretation of their SSR patterns. All the above mentioned taxa are perennial and were identified in different Natura 2000 sites from Romania. Besides D. nardiformis, which is found not only in eastern Romania but also in northern Bulgaria, all the other 4 species are found only in Romania and are strictly endemic to the above mentioned areas.

\section{Materials and methods}

\section{Plant material}

The plant material was collected from different populations of the studied Dianthus taxa from Romania (Fig. 1).

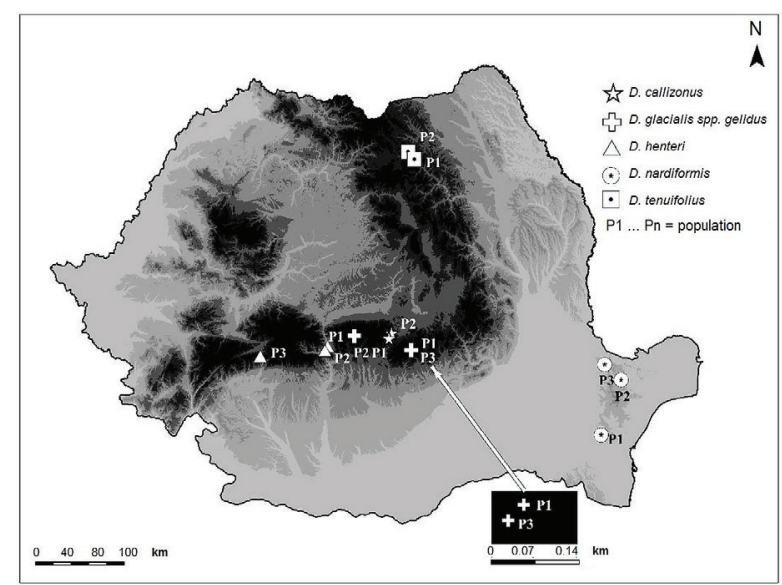

Fig. 1. Sampling locations for Dianthus populations in Romania.

Five individuals were collected from each location. Thus, D. callizonus was collected from 2 locations from Piatra Craiului Mountains: P1-Spîrlea refuge and Zăplaz

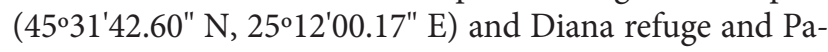

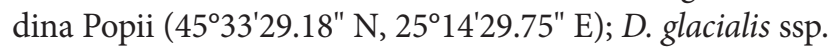
gelidus from 3 populations from Bucegi Mountains: P1-

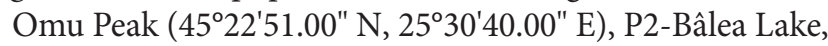

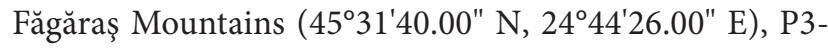

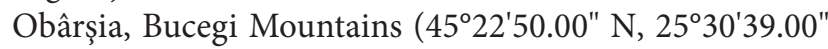
$\mathrm{E})$; D. henteri from 3 populations from Vâlcea county: P1-Cornet (4523'19.82" N, 24²18'28.54" E), P2-Călineşti

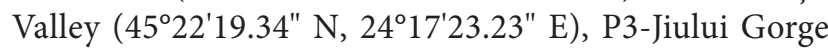
$\left(45^{\circ} 16^{\prime} 46.00^{\prime \prime} \mathrm{N}, 23^{\circ} 23^{\prime} 19.00^{\prime \prime} \mathrm{E}\right)$; D. nardiformis from 3 populations from Tulcea county: P1-Allah Bair (44 $29^{\prime} 01.42^{\prime \prime} \mathrm{N}$, $28^{\circ} 13^{\prime} 24.88^{\prime \prime}$ E), P2-Consul Hill (4510'55.19" N; 28¹6'15.77"

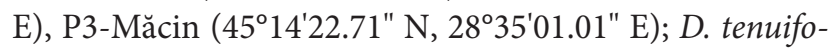
lius from 2 populations from Suceava county: P1-Stânişoarei Mountains ( $\left.47^{\circ} 21^{\prime} 50.87^{\prime \prime} \mathrm{N}, 2^{\circ} 36^{\prime} 10.88^{\prime \prime} \mathrm{E}\right)$, P2-Bistriței Mountains $\left(47^{\circ} 23^{\prime} 30.00^{\prime \prime} \mathrm{N}, 25^{\circ} 30^{\prime} 16.65^{\prime \prime} \mathrm{E}\right)$.

\section{SSR analysis}

Genomic DNA was isolated from leaves using the CTAB method described by Doyle and Doyle (1987). For SSR analysis, a total of five primer pairs (On-line Suppl. Tab. 1) were used (Smulders et al. 2000). PCR amplifications were performed in a $0.2 \mathrm{~mL}$ tube containing $2 \mathrm{mM} \mathrm{MgCl}, 1 \mu \mathrm{M}$ of each primer, $200 \mu \mathrm{M}$ of each dNTP, $1.5 \mathrm{U}$ of Taq (Fermentas) and 25 ng of genomic DNA in a final volume of $25 \mu \mathrm{L}$. DNA amplification was performed according to the following program: $1 . \mathrm{T}=94^{\circ} \mathrm{C}, 5 \mathrm{~min} ; 2 . \mathrm{T}=94^{\circ} \mathrm{C}, 45 \mathrm{~s} ; 3$. primer annealing at $55^{\circ} \mathrm{C}, 45 \mathrm{~s}$; 4 . elongation $\mathrm{T}=72{ }^{\circ} \mathrm{C}, 45 \mathrm{~s}$; steps 2-4 were repeated 35 times. Amplicons were separated on $1.5 \%$ agarose gel, stained with $0.5 \mu \mathrm{g} \mathrm{mL} \mathrm{m}^{-1}$ ethidium bromide. At least 2 independent PCR amplifications were performed for each primer.

\section{Data analyses}

Several genetic diversity parameters were calculated for each locus and per Dianthus species using POWERMARKER 3.25 (Liu and Muse 2005). These included gene diversity (expected heterozygosity), observed heterozygosity (referred 
Tab. 1. Genetic characterization of Dianthus species based on SSR alleles. Different types of alleles: $a$-BSY-150, $b$-BSY-100, $c$-BSY-75, $d$ BSY-50, $e$-DIA-200, $f$-DIA-175, $g$-DIA-100, $h$-DIA-75, $i$-DIA-50, $j$-DINCA-200, $k$-DINCA-150, $l$-DINCA-100, $m$-DINCA-50, $n$-DINGSTA-200, $o$-DINGSTA-175, $p$-DINGSTA-100, $r$-DINGSTA-75, $s$-BOX-300, $t$-BOX-175, $u$-BOX-150, $v$-BOX-100, $x$-BOX-75, $z$-BOX-50, absence of allele.

\begin{tabular}{|c|c|c|c|c|c|c|c|c|}
\hline 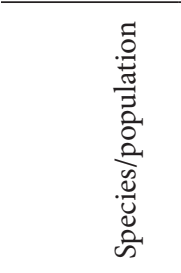 & & : & 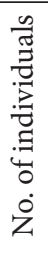 & 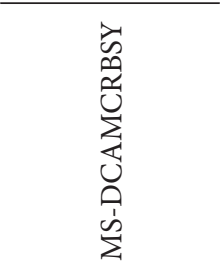 & 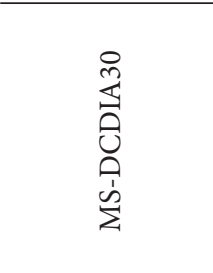 & 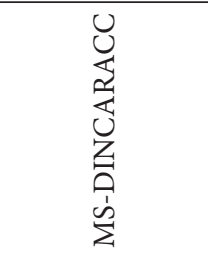 & 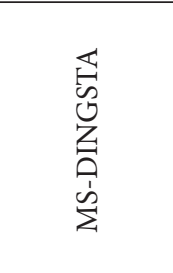 & 岕离 \\
\hline D. callizonus & P1 & $\begin{array}{l}\text { Spîrlea refuge and } \\
\text { Zăplaz, Diana refuge } \\
\text { and Padina Popii, } \\
\text { Piatra Craiului } \\
\text { Mountains }\end{array}$ & 5 & $\begin{array}{c}\text { 1-2 alleles: } \\
\text { 100:75 } \\
(-b, b c)\end{array}$ & $\begin{array}{l}2 \text { alleles: } 100: 75 \\
(g h)\end{array}$ & $\begin{array}{l}1 \text { allele: } 100 \\
\text { (l) }\end{array}$ & $\begin{array}{l}1 \text { allele: } 100 \\
(p)\end{array}$ & $\begin{array}{l}1 \text { allele: } 100 \\
(v)\end{array}$ \\
\hline \multirow[t]{3}{*}{$\begin{array}{l}\text { D. glacialis } \\
\text { ssp. gelidus }\end{array}$} & P1 & $\begin{array}{l}\text { Omu Peak, Bucegi } \\
\text { Mountains }\end{array}$ & 5 & $\begin{array}{l}\text { 0-1 alleles: } 100 \\
(b-)\end{array}$ & $\begin{array}{c}\text { 1-2 alleles: } \\
\text { 200:50 } \\
(e i,-i)\end{array}$ & $\begin{array}{c}\text { 1-2 alleles: } \\
\text { 200:50 } \\
(j m,-m)\end{array}$ & $\begin{array}{l}1 \text { allele: } 75 \\
\quad(r)\end{array}$ & $\begin{array}{c}\text { 0-2 alleles: } \\
\text { 150:100:75 } \\
(v x, u x,--, x-)\end{array}$ \\
\hline & P2 & $\begin{array}{l}\text { Bâlea Lake, Făgăraş } \\
\text { Mountains }\end{array}$ & 5 & $\begin{array}{c}\text { 1-2 alleles: } \\
\text { 100:75 } \\
(b-, b c)\end{array}$ & $\begin{array}{l}\text { 1-2 alleles: } \\
\text { 200:50 } \\
(e i,-i)\end{array}$ & $\begin{array}{c}\text { 1-2 alleles: } \\
\text { 200:50 } \\
(j m,-m)\end{array}$ & $\begin{array}{l}1 \text { allele: } 75 \\
\quad(r)\end{array}$ & $\begin{array}{c}\text { 1-2 alleles: } \\
\text { 150:75:50 } \\
\left(u z, x_{-}\right)\end{array}$ \\
\hline & P3 & $\begin{array}{l}\text { Obârşia, Bucegi } \\
\text { Mountains }\end{array}$ & 5 & $\begin{array}{c}\text { 1-2 alleles: } \\
\text { 150:50 } \\
(a d, b-)\end{array}$ & $\begin{array}{c}\text { 1-2 alleles: } \\
\text { 200:50 } \\
(-i, e i)\end{array}$ & $\begin{array}{c}\text { 1-2 alleles: } \\
200: 50 \\
(j m,-m)\end{array}$ & $\begin{array}{l}1 \text { allele: } 75 \\
(r)\end{array}$ & $\begin{array}{l}\text { 1-2 alleles: } \\
\text { 150:75:50 } \\
(u z,-z, x-)\end{array}$ \\
\hline \multirow[t]{3}{*}{ D. henteri } & P1 & Cornet, Vâlcea county & 5 & $\begin{array}{l}2 \text { alleles: } 100: 50 \\
(b d)\end{array}$ & $\begin{array}{c}\text { 1-2 alleles: } \\
200: 75 \\
(e h,-h)\end{array}$ & $\begin{array}{c}\text { 2 alleles: } \\
\text { 200:150:100 } \\
(j k, k l)\end{array}$ & $\begin{array}{c}2 \text { alleles: } \\
\text { 200:75 } \\
(n r)\end{array}$ & $\begin{array}{c}\text { 1-2 alleles: } \\
\text { 150:100 } \\
(u v,-v)\end{array}$ \\
\hline & P2 & $\begin{array}{l}\text { Călineşti Valey, Vâlcea } \\
\text { county }\end{array}$ & 5 & $\begin{array}{l}2 \text { alleles: 100:50 } \\
\qquad(b d)\end{array}$ & $\begin{array}{l}\text { 1-2 alleles: } \\
\text { 200:75 } \\
(e h,-h)\end{array}$ & $\begin{array}{l}2 \text { alleles: } \\
\text { 200:150:100 } \\
\quad(j k, k l)\end{array}$ & $\begin{array}{c}2 \text { alleles: } \\
\text { 200:75 } \\
(n r)\end{array}$ & $\begin{array}{l}\text { 1-2 alleles: } \\
\text { 150:100 } \\
(u v,-v)\end{array}$ \\
\hline & P3 & Jiului Gorge & 5 & $\begin{array}{l}2 \text { alleles: } 100: 50 \\
(b d)\end{array}$ & $\begin{array}{l}\text { 0-1 alleles: } 75 \\
(-h)\end{array}$ & $\begin{array}{c}2 \text { alleles: } \\
\text { 150:100 } \\
(k l)\end{array}$ & $\begin{array}{c}\text { 1-2 alleles: } \\
\text { 200:75 } \\
(n r,-r)\end{array}$ & $\begin{array}{c}0-1 \text { alleles: } \\
100 \\
(-v)\end{array}$ \\
\hline \multirow[t]{3}{*}{$\begin{array}{c}D . \\
\text { nardiformis }\end{array}$} & $\mathrm{P} 1$ & $\begin{array}{l}\text { Allah Bair, Tulcea } \\
\text { county }\end{array}$ & 5 & $\begin{array}{l}0-1 \text { alleles: } 100 \\
(-b,--)\end{array}$ & $\begin{array}{l}\text { 1-2 alleles: } \\
\text { 200:75 } \\
(-h, e h)\end{array}$ & $\begin{array}{c}\text { 1-2 alleles: } \\
\text { 150:100 } \\
(-l, k l)\end{array}$ & $\begin{array}{l}\text { 1-2 alleles: } \\
\text { 200:100 } \\
(n-, n p)\end{array}$ & $\begin{array}{c}\text { 1-2 alleles: } \\
\text { 150:75 } \\
(-u, u x)\end{array}$ \\
\hline & $\mathrm{P} 2$ & $\begin{array}{l}\text { Consul Hill, } \\
\text { Tulcea county }\end{array}$ & 5 & $\begin{array}{l}\text { 0-1 alleles: } \\
\text { 150:100 } \\
(a-,-b)\end{array}$ & $\begin{array}{l}\text { 1-2 alleles: } \\
\text { 200:75 } \\
(-h, e h)\end{array}$ & $\begin{array}{c}\text { 1-2 alleles: } \\
\text { 150:100 } \\
(k l, k-)\end{array}$ & $\begin{array}{l}\text { 1-2 alleles: } \\
\text { 200:100 } \\
(n-, n p)\end{array}$ & $\begin{array}{c}\text { 1-2 alleles: } \\
\text { 150:75 } \\
(-u, u x)\end{array}$ \\
\hline & P3 & Măcin, Tulcea county & 5 & $\begin{array}{l}0-1 \text { alleles: } 100 \\
(a-)\end{array}$ & $\begin{array}{l}\text { 1-2 alleles: } \\
\text { 200:75 } \\
(-h, e h)\end{array}$ & $\begin{array}{c}\text { 1-2 alleles: } \\
\text { 150:100 } \\
(-l, k l)\end{array}$ & $\begin{array}{c}\text { 1-2 alleles: } \\
\text { 200:100 } \\
(-p, n p) \\
\end{array}$ & $\begin{array}{c}\text { 1-2 alleles: } \\
\text { 150:75 } \\
(-x, u x) \\
\end{array}$ \\
\hline \multirow[t]{2}{*}{$\begin{array}{c}D . \\
\text { tenuifolius }\end{array}$} & P1 & $\begin{array}{l}\text { Stânişoarei Mountains, } \\
\text { Suceava county }\end{array}$ & 5 & $\begin{array}{l}0-1 \text { alleles: } 100 \\
(a-)\end{array}$ & $\begin{array}{c}2 \text { alleles: } \\
175: 75 \\
f h\end{array}$ & $\begin{array}{l}0-1 \text { alleles: } 100 \\
(l,--)\end{array}$ & $\begin{array}{l}\text { 1-2 alleles: } \\
\text { 200:175:75 } \\
\text { (or, r-, no) }\end{array}$ & $\begin{array}{l}\text { 1-2 alleles: } \\
\text { 300:150:75 } \\
(-x, u x, s u)\end{array}$ \\
\hline & $\mathrm{P} 2$ & $\begin{array}{l}\text { Bistriței Mountains, } \\
\text { Suceava county }\end{array}$ & 5 & $\begin{array}{c}\text { 1-2 alleles: } \\
\text { 150:75 } \\
(a-, a c,-c)\end{array}$ & $\begin{array}{l}0-1 \text { alleles: } 75 \\
(-h)\end{array}$ & $\begin{array}{l}0-1 \text { alleles: } 100 \\
(l,-)\end{array}$ & $\begin{array}{c}\text { 1-2 alleles: } \\
\text { 175:75 } \\
(\text { or, }-r)\end{array}$ & $\begin{array}{c}2 \text { alleles: } \\
\text { 300:150 } \\
(s u)\end{array}$ \\
\hline
\end{tabular}

to as heterozygosity), and polymorphism information content (PIC) value. These parameters take into account allele frequencies. Within species, richness and evenness were also explored using GENALEX6.5 (Peakall and Smouse 2006, 2012). The number of alleles per species (arithmetic mean across loci), the number of alleles with a frequency greater than $5 \%$, the effective number of alleles, the number of private alleles and the number of locally common alleles occurring in less than $50 \%$ of the populations were explored. Genetic diversity was assessed via Shannon's information in- dex, on a single-locus basis, based on natural logarithmic allele frequencies. The evolutionary history was inferred using the neighbour-joining method (Saitou and Nei 1987). The optimal tree with the sum of branch length $=100.13433838$ was constructed. The tree was drawn to scale, with branch lengths in the same units as those of the evolutionary distances used to infer the phylogenetic tree. The evolutionary distances were provided by the user. Evolutionary analyses were conducted in MEGA 6 (Tamura et al. 2013). Principal coordinate analysis (PCoA) was used to explore multivariate 
relationships among inter-individual genetic distances within each species and among Dianthus populations. Additionally, divergence statistics were computed using the analysis of molecular variance (AMOVA) implemented in ARLEQUIN 3.5 (Excoffier and Lischer 2010).

\section{Results}

\section{Genetic polymorhism}

All loci amplified well in nearly all individuals tested. A total of 23 polymorphic alleles were amplified. The number of alleles per locus and the frequency in each species is shown in On-line Suppl. Tab. 2. The average number of alleles was 4.6. The genetic variation within populations is generally low. Almost all the individuals belonging to a population share the same alleles. The allelic composition of each SSR locus based on the results of all five Dianthus species is detailed in Tab. 1. The most frequent allele in the locus BSY was $b$ in all species except $D$. tenuifolius and the allele $d$ had the lowest frequency, being present only in $D$. henteri individuals. In the locus DIA the most frequent allele was $h$, while the alleles $f$ and $g$ had the lowest frequencies. In the locus DINCA the most frequent allele was $l$ and the least frequent was $m$. The most frequent allele in the locus DINGSTA was $r$ and the lowest frequency was observed for the allele $o$. In the locus BOX the highest frequency was observed for allele $x$ and the lowest frequency for allele $z$. The alleles $b, l$ and $v$ were present in most of the species, while the allele $g$ was present only in D. callizonus. Individuals of D. glacialis ssp. gelidus showed a particular combination of alleles in most of the loci, the alleles $i$ and $m$. Other alleles, $j$ and $r$, were present only in some individuals of $D$. henteri and D. tenuifolius. The individuals belonging to $D$. henteri species showed the particular allele $d$ and the allele $v$ which was present in D. callizonus as well. D. tenuifolius showed a particular combination of alleles, the allele $a$ which was also present only in $D$. nardiformis and the allele $c$ also present in D. callizonus. The alleles $f, o$ and $s$, were present only in D. tenuifolius.

In our study the gene diversity is low, ranging from 0.18 to 0.44 , the lowest gene diversity being observed in $D$. callizonus (Tab. 2). The proportion of the heterozygous individuals (observed heterozygosity) ranged between 0.3 and 0.57 , the lowest value being observed again in $D$. callizonus. The distribution power of the SSR marker, estimated by the polymorphism information content (PIC) value ranged between 0.14 (D. callizonus) and 0.34 (D. henteri) (Tab. 2).

Tab. 2. Mean gene diversity (He), heterozygosity (Ho) and polymorphism information content (PIC) values of the 5 studied Dianthus species.

\begin{tabular}{lccc}
\hline Species & $\mathrm{He}$ & $\mathrm{Ho}$ & PIC \\
\hline D. callizonus & 0.18 & 0.3 & 0.14 \\
D. glacialis ssp. gelidus & 0.31 & 0.32 & 0.26 \\
D. henteri & 0.44 & 0.57 & 0.34 \\
D. nardiformis & 0.35 & 0.32 & 0.28 \\
D. tenuifolius & 0.4 & 0.47 & 0.32 \\
\hline
\end{tabular}

High similarity among Dianthus species collected from Romania was observed in this study. Allelic patterns across Dianthus species, as revealed in Fig. 2, indicate that the mean number of different alleles was highest in D. glacialis ssp. gelidus, while the number of effective alleles was found to be higher in $D$. tenuifolius. The amount of alleles with a frequency equal to or higher than $5 \%$ was similar in all five species, excepting for D. callizonus, where it was slightly lower. Except for D. nardiformis, private alleles were detected in all Dianthus populations. The strongest genetic divergence was observed among $D$. callizonus and D. tenuifolius. The number of locally common alleles with a frequency higher than $5 \%$ revealed that $D$. henteri and $D$. nardiformis share almost the same alleles in most of the loci. Shannon's information index (I) reveals low levels of genetic diversity in all populations, especially in $D$. callizonus $(I=0.251)$. D. henteri was characterized by the highest genetic diversity $(\mathrm{I}=0.626)$. Moreover, Shannon's index was closely related to the expected heterozygosity. A high similarity in allelic patterns was observed in case of $D$. henteri and $D$. tenuifolius.

\section{Genetic structure and evolutionary analysis}

A neighbour-joining tree showed the evolutionary relationships of taxa (Fig. 3). Thus, some of the individuals belonging to D. henteri, D. glacialis and D. callizonus clustered independently while an overlapping distribution was observed in case of $D$. nardiformis and D. tenuifolius and other individuals of previous species. This distribution was confirmed by principal coordinate analysis (PCoA). This analysis shows a relatively high diversity of patterns in $D$. nardiformis and D. glacialis ssp. gelidus. Consistent with the low levels of genetic diversity, a low variety of allelic profiles was observed in D. callizonus population (Fig. 4). The first, the second and the third principal coordinates accounted for $32.27 \%, 18.69 \%$ and $11.99 \%$, respectively, explaining for 62.96 of the total genetic variation across individuals belonging to different Dianthus species.

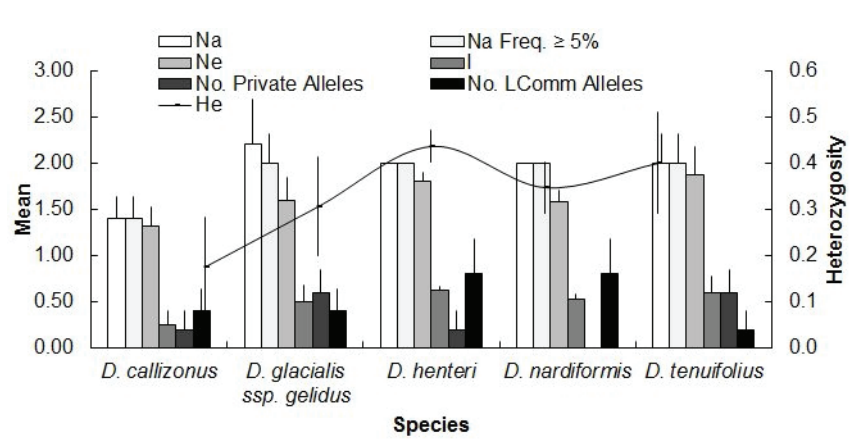

Fig. 2. Distribution of allelic patterns across Dianthus species. $\mathrm{Na}$ - number of different alleles; Na Freq $\geq 5 \%$ - number of different alleles with a frequency $\geq 5 \%$; $\mathrm{Ne}$ - number of effective alleles; I - Shannon's information index; No. Private Alleles - number of alleles unique to a single species; No. LComm Alleles - number of locally common alleles with a frequency $\geq 5 \%$ found in $50 \%$ or fewer species; $\mathrm{He}$ - Expected heterozygosity. Error bars represent standard deviations. 
Analysis of molecular variance (AMOVA) for all loci showed that the highest amount of genetic variance $(51.48 \%)$ occurred among Dianthus species and a variance of $48.52 \%$ was found within the species. Locus-by-locus AMOVA con-

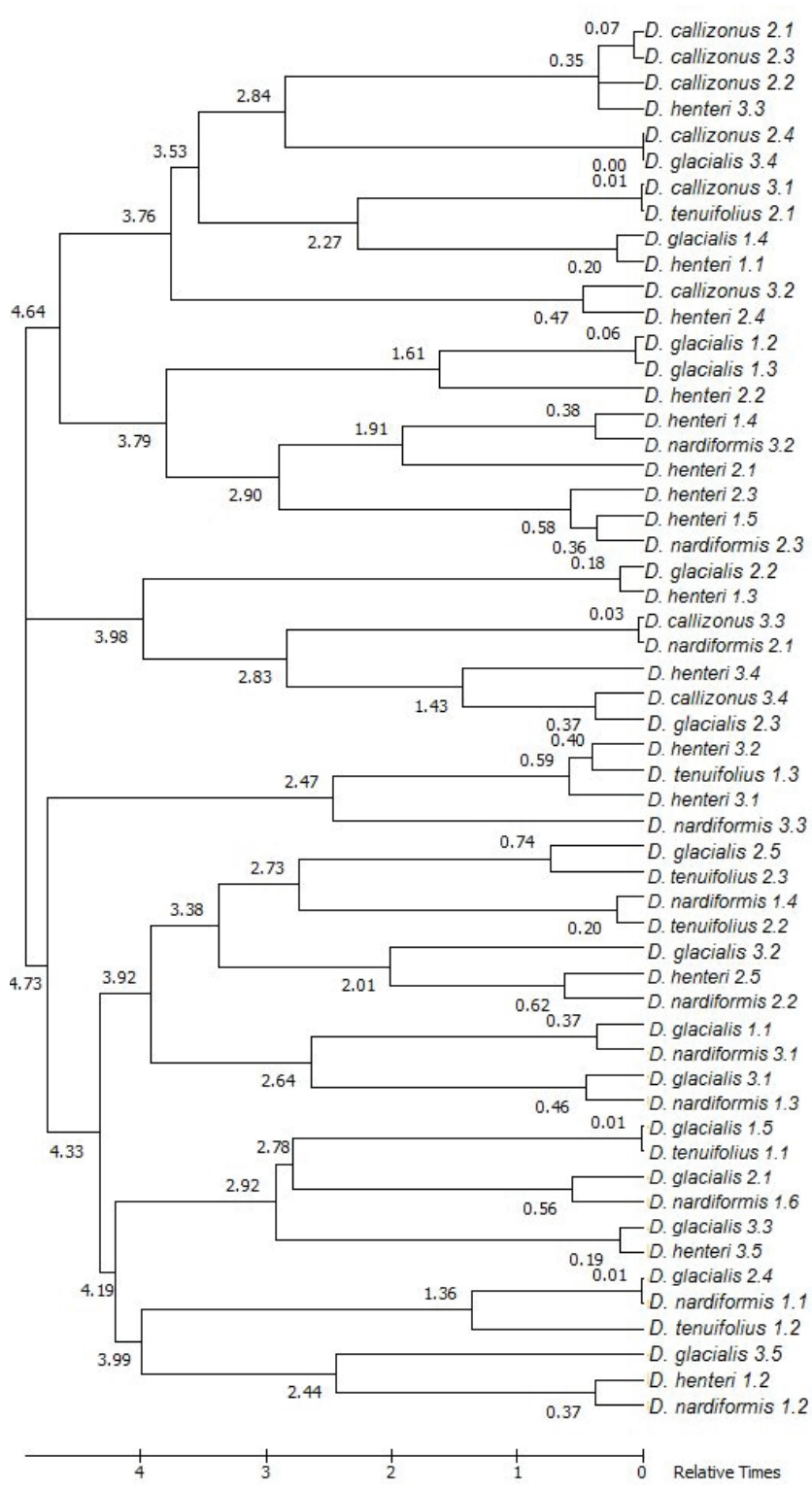

Fig. 3. Evolutionary relationships of Dianthus taxa in Romania.

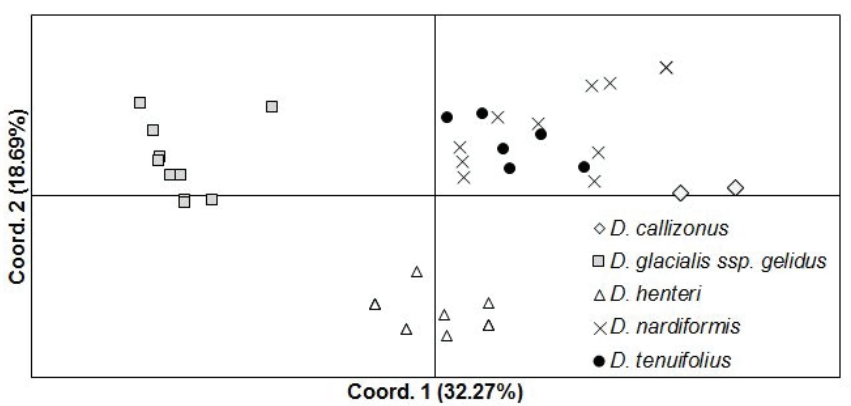

Fig. 4. A two-dimensional plot of the principal coordinate analysis (PCoA) of SSR data showing the clustering of five Dianthus species in Romania. firmed the results of the overall AMOVA and revealed that the greatest amount of genetic variance occurred among all five Dianthus species (50.88\%). Genetic variance found within Dianthus species was $49.12 \%$ (Tab. 3).

Tab. 3. Results of analysis of molecular variance (AMOVA) based on $\mathrm{F}_{\mathrm{ST}}$ from data of five microsatellite loci and Gini-Simpson index of Dianthus species.

\begin{tabular}{ccccc}
\hline $\begin{array}{c}\text { Source of } \\
\text { variation }\end{array}$ & $\begin{array}{c}\text { Degrees of } \\
\text { freedom }\end{array}$ & $\begin{array}{c}\text { Sum of } \\
\text { squares }\end{array}$ & $\begin{array}{c}\text { Variance } \\
\text { components }\end{array}$ & $\begin{array}{c}\text { Percentage } \\
\text { variation } \\
(\mathrm{p}<0.001)\end{array}$ \\
\hline \multicolumn{5}{c}{ AMOVA analysis for all loci } \\
\hline Among species & 4 & 66.876 & 0.748 & 51.48 \\
Within species & 105 & 74.042 & 0.705 & 48.52 \\
\hline \multicolumn{5}{c}{ Locus by locus AMOVA } \\
\hline Among species & 83.317 & 0.961 & 50.88 \\
Within species & 94.336 & 0.927 & 49.12 \\
\hline
\end{tabular}

\section{Discussion}

\section{Genetic diversity of Romanian Dianthus taxa}

Molecular investigation of Dianthus species from Europe has recently aroused interest in several aspects. Analysis of the genetic diversity and structure of populations of endangered, rare or endemic species of Dianthus are useful tools in conservation planning. Molecular analysis could aid especially in the case of plant species capable of clonal propagation as Dianthus. In many cases, endangered, rare or endemic species with large populations can be genetically similar or identical. In spite of the high number of individuals, the low genetic diversity variation is due to clonal multiplication or bottlenecks. Thus, data about genetic structure and variability should be useful before the development of proper conservation strategies. There are few data about molecular analysis of rare or endemic Dianthus species (Cristea et al. 2014, Jarda et al. 2014) despite the numerous data regarding the conservation of these species. In Romania these plant species were preserved by in vitro cultures (Butiuc-Keul et al. 2001, Miclăuş et al. 2003, Cristea et al. 2006, 2010, Marcu et al. 2006, Jarda et al. 2011, 2014). Our study revealed the genetic diversity structure of 5 endangered or endemic species of Dianthus found in different sites in Romania. Most of these locations have been designated NATURA 2000 Sites. By the use of SSR markers developed with the 5 primer pairs tested in this study, 10-11 alleles from a total of 23 polymorphic alleles amplified were identified in most of the species. The population of $D$. callizonus showed the lowest diversity, probably as a result of limited distribution (this is a local endemic species). According to these results, D. callizonus conservation should be a priority for the administration of the Piatra Craiului Natural Park. A single allele was identified in each of the loci MS-DINCARACC, MS-DINGSTA and MS-DINMADSBOX and 2 alleles were identified in loci MS-DCAMCRBSY and MS-DCDIA30.

The highest diversity was revealed in the populations of D. glacialis ssp. gelidus, especially in locus MS-DINMADS- 
BOX (4 from the 6 alleles observed). This highest diversity can be explained by its larger distribution area.

Regarding the genetic diversity among populations of the same species, no differences were revealed by SSR markers tested in the present study. The highest genetic diversity was observed in D. glacialis ssp. gelidus and D. tenuifolius in locus MS-DINMADSBOX.

The genetic diversity is generally low in the Dianthus species studied here. This may be related to several factors. Mountain and alpine plants have to cope with harsh environmental conditions, e.g. short vegetation periods, unstable and low-fertility soils, desiccating winds, and high solar radiation, thus a population with low genetic diversity has limited possibilities to fight against harsh environmental conditions. In the short term, a loss of genetic diversity can reduce plant performance and population viability and may limit the potential for further adaptive evolution (Ellstrand and Elam 1993). Low genetic diversity could also be explained by the clonal propagation of many plants, as in Dianthus species grown in severe environmental conditions (Stöcklin 1992). Clonal propagation usually produces a rapid, but spatially limited spread of genotypes. Along an altitudinal gradient, the vegetative growth is increased, because reproduction by seeds may be hampered by the harsh alpine conditions (Young et al. 2002, Gabel et al. 2017).

The low values of gene diversity, heterozygosity and PIC found in our study are in accord with other data showing low diversity and polymorphism of Dianthus species from the Iberian Peninsula (Balao et al. 2010) and Iran (Farsi et al. 2013). These data seem to suggest that Dianthus species may be in general very young and the Romanian species are not an exception to the pattern.

It is well known that small populations isolated in fragmented habitats contain less genetic diversity than larger populations because over time, individuals will become more homozygous due to the low amounts of available genetic diversity within the population and increased inbreeding (Duminil et al. 2007). There are also complex interactions between small population size, genetic diversity and individual fitness (Aguilar et al. 2008) with several consequences, such as inbreeding depression (Jolivet et al. 2013). Human activity and land use changes was followed by smallscale fragmentation of grassland habitats in most regions of central Europe, thus small populations are facing extinction due to local maladaptation in remnant habitats (Busch et al. 2016). In Romania, populations of these endangered species of Dianthus seems to be also such small populations with low adaptation to the habitats. On the other hand in the case of D. gratianopolitanus, genetic variation within populations seems to be much more affected by population density and size than by isolation. Thus, genetic variation decreases with increasing population density across all studied populations, which may be due to the effect of gene flow within populations, which should be stronger in dense populations. Genetic variation was higher among populations of $D$. gratianopolitanus in Germany than in Switzerland. In the German region with a higher magnitude of isolation, genetic varia- tion within populations depended on population size. In the Swiss study region, with a lower magnitude of isolation, the higher genetic variations may be attributed to the gene flow among populations even within smaller populations (Putz et al. 2015). Other studies showed that the historical landscape structure may be more important for genetic diversity than present habitat conditions. Thus, populations that were persisting in abandoned grassland fragments significantly influence the genetic variability of those species even under deteriorating habitat conditions. All of these studies may lead to the conclusion that individuals from different populations should be included in approaches to preserve the genetic variation of such plant species (Reisch et al. 2017).

\section{Evolutionary framework and genetic variation of the studied carnations}

Dianthus genus is characterized by its extensive morphological and genetic variability (Erhardt 1990, 1991, Friedman et al. 2001, Bloch et al. 2006). Many phylogenetic studies revealed that evolutionary radiations have occurred in Dianthus (Balao et al. 2010, Valente et al. 2010). Polyploi$\mathrm{dy}$, hybridization, and genome duplication, are common evolutionary forces in plants and act as potential drivers of plant radiation (Otto 2007, Paun et al. 2009, Soltis and Soltis 2009). Although interspecific hybridization is feasible in several clades of Dianthus (Collin and Shykoff 2003), it seems, however, that the incomplete lineage sorting and/or ancestral polymorphism processes have played a prominent roles in its recent evolutionary history (Balao et al. 2010, Valente et al. 2010). Hybridization is exceptionally high in Dianthus compared to many genera, partly in consequence of the recent origin of most species. High rates of hybridization have possibly contributed to fast diversification by providing evolutionary potential via lineage fusions and may explain the shared alleles.

One of the phylogenetic studies of the genus revealed that rates of diversification in Mediterranean Dianthus have been exceptionally high (Valente et al. 2010) and suggest that a combination of polyploidy and geographical speciation may have driven cladogenesis in the group. The major patterns of variation within and among populations of particular species on mountains have not been clearly described to date, and thus it has been difficult to discuss our results of specific case studies in relation to general patterns. However a recent study based on morphological and molecular data and analyses suggest that Dianthus binaludensis, distributed on Binalud Mountain, northeast Iran, also displays a local morphological divergence (Farsi et al. 2013).

In conclusion, the gene diversity is low in all of the five endemic or rare species of Dianthus. The genetic structure is similar in their different populations, D. callizonus and $D$. tenuifolius show particular sets of SSR alleles, the other 3 species of D. glacialis ssp. gelidus, D. henteri and D. nardiformis share almost the same alleles in most of the loci. Our results of evolutionary neighbour-joining analysis show overlapping distribution in the case of D. nardiformis, D. tenuifolius and several individuals of $D$. henteri, $D$. glacialis and $D$. callizonus. 
This phenomenon could occur from the evolutionary processes in recently differentiated species such as Dianthus species (Balao et al. 2010, Valente et al. 2010). From these data we suggest that $D$. henteri, D. glacialis have not yet fully diverged. Although these two species clustered independently, several individuals clustered together with other species.

\section{References}

Aguilar, R., Quesada, M., Ashworth, L., Herrerias-Diego, Y., Lobo, J., 2008: Genetic consequences of habitat fragmentation in plant populations: susceptible signals in plant traits and methodological approaches. Molecular Ecology 17, 5177-5188.

Balao, F., Valente, L. M., Vargas, P., Herrera, J., Talavera, S., 2010: Radiative evolution of polyploid races of the Iberian carnation Dianthus broteri (Caryophyllaceae). New Phytologist 187, 542-551.

Bloch, D., Werdenberg, N., Erhardt, A., 2006: Pollination crisis in the butterfly-pollinated wild carnation Dianthus carthusianorum? New Phytologist 169, 699-706.

Breinholt, J. W., Buren, V. R., Kopp, O. R., Stephen, C. L., 2007: Population genetic structure of an endangered Utah endemic, Astragalus ampullarioides (Fabaceae). American Journal of Botany 96, 661-667.

Busch, V., Reisch, C., 2016: Population size and land use affect the genetic variation and performance of the endangered plant species Dianthus seguieri ssp. glaber. Conservation Genetics 17, 425-436.

Butiuc-Keul, A., Şuteu, A., Munteanu-Deliu, C., Deliu, C., 2001: Study on the in vitro preservation of Dianthus spiculifolius Schur. Contributii Botanice 36, 137-147.

Carolin, R. C., 1957: Cytological and hybridization studies in the genus Dianthus. New Phytologist 56, 81-97.

Ciocârlan, V., 2009: Pictured Flora of Romania. Ceres, Bucureşti (in Romanian).

Collin, C. L., Shykoff, J.A., 2003: Outcrossing rates in the Gynomonoecious-Gynodioecious species Dianthus sylvestris (Caryophyllaceae). American Journal of Botany 90, 579-585.

Cristea, V., Puşcaş, M., Miclăuş, M., Deliu, C., 2006: Conservative micropropagation of some endemic or rare species from the Dianthus genus. Acta Horticulturae 725, 357-364.

Cristea, V., Brummer, A. T., Jarda, L., Miclăuş, M., 2010: In vitro culture initiation and phytohormonal influence on Dianthus henteri-a Romanian endemic species. Romanian Biotechnological Letters 25, 25-33.

Cristea, V., Crăciunaş, C., Marcu, D., Palada, M., Butiuc-Keul, A., 2014: Genetic stability during in vitro propagation of Dianthus spiculifolius Schur. Propagation of Ornamental Plants $14,26-31$.

Cruzan, M. B., 2001: Population size and fragmentation thresholds for the maintenance of genetic diversity in the endemic, Scutellaria montana (Lamiaceae). Evolution 55, 1569-1580.

Dihoru, G., Negrean, G., 2009: Red Book of Vascular Plants of Romania. Editura Academiei Române, București (in Romanian).

Doyle, J., Doyle, J. L., 1987: A rapid DNA isolation procedure for small quantities of fresh leaf tissue. Phytochemical Bulletin 19, 11-15.

Duminil, J., Fineschi, S., Hampe, A., Jordano, P., Salvini, D., Vendramin, G. G., Petit, R. J., 2007: Can population genetic structure be predicted from life-history traits. The American Naturalist $169,662-672$.

Ellstrand, N., Elam, D., 1993: Population genetic consequences of small population size: Implications for plant conservation.

\section{Acknowledgments}

This work was supported by the projects 31-008/2007 and 71/2014, Partnerships in priority areas - PN II, financed by Romanian Ministry of National Education (CNMP and UEFISCDI). Many thanks to Dr. Irina Holobiuc, Dr. Mihai Puşcaş and Dr. Adrian Oprea for collecting plant material.

Annual Review of Ecology, Evolution, and Systematics 24, 217-242.

Erhardt, A., 1990: Pollination of Dianthus gratianopolitanus Vill. Plant Systematics and Evolution 170, 125-132.

Erhardt, A., 1991: Pollination of Dianthus superbus L. Flora 185, 99-106.

Excoffier, L., Lischer, H. E. L., 2010: ARLEQUIN suite ver 3.5: a new series of programs to perform population genetics analyses under Linux and Windows. Molecular Ecology Resources 10, 564-567.

Frankham, R., 2006: Relationship of genetic variation to population size in wildlife. Conservation Biology 10, 1500-1508.

Farsi, M., Behroozian, M., Vaezi, J., Joharchi, M. R., Memariani, F., 2013: The evolution of Dianthus polylepis complex (Caryophyllaceae) inferred from morphological and nuclear DNA sequence data: one or two species? Plant Systematics and Evolution 299, 1419-1431.

Friedman, H., Hagiladi, A., Resnick, N., Barak, A., Umiel, N., 2001: Ethylene-insensitive related phenotypes exist naturally in a genetically variable population of Dianthus barbatus. Theoretical and Applied Genetics 103, 282-287.

Fu, X., Ning, G., Gao, L., Bao, M., 2008: Genetic diversity of Dianthus accessions as assessed using two molecular marker systems (SRAPs and ISSRs) and morphological traits. Scientia Horticulturae 117, 263-270.

Gabel, A. R., Sattler, J., Reisch, C., 2017: Genetic variation and performance of the alpine plant species Dianthus callizonus differ in two elevational zones of the Carpathians. Alpine Botany $127,65-74$.

Gitzendanner, M. A., Soltis, P. S., 2000: Patterns of genetic variation in rare and widespread plant congeners. American Journal of Botany 87, 783-792.

Hamrick, J. L., Godt, M. J. W., Murawski, D. A., Loveless, M. D., 1991: Correlations between species traits and allozyme diversity: Implications for conservation biology. In: Falk, D. A., Holsinger, K. E. (eds.), Genetics and conservation of rare plants, 75-86. Oxford University Press, New York.

Ilves, A., Lanno, K., Sammul, M., Tali, K., 2013: Genetic variability, population size and reproduction potential in Ligularia sibirica (L.) populations in Estonia. Conservation Genetics 14, 661-669.

Jarda, L., Cristea, V., Halmagyi, A., Palada, M., 2011: In vitro culture initiation and cryopreservation of endemic taxa Dianthus giganteus ssp. banaticus. Acta Horticuturae 918, 153-159.

Jarda, L., Butiuc-Keul, A., Höhn, M., Pedryc, A., Cristea, V., 2014: Ex situ conservation of Dianthus giganteus d'Urv. subsp. banaticus (Heuff.) Tutin by in vitro culture and assessment of somaclonal variability by molecular markers. Turkish Journal of Biology 38, 21-30.

Johansson, M., Primmer, C. R., 2007: Merila J. Does habitat fragmentation reduce fitness and adaptability? A case study of the common frog (Rana temporaria). Molecular Ecology 16, 2693-2700. 
Jolivet, C., Rogge, M., Degen, B., 2013: Molecular and quantitative signatures of biparental inbreeding depression in the self-incompatible tree species Prunus avium. Heredity 110, 439-448.

Kang, M., Ye, Q., Huang, H., 2005: Genetic consequences of restricted habitat and population decline in endangered Isoete sinensis (Isoetaceae). Annals of Botany 96, 1265-1274.

Katoh, S., Kaneko, S., Isagi, Y., Murakami, N., Kato, H., 2007: Isolation and characterization of microsatellite loci in Melicope quadrilocularis (Rutaceae), an endemic plant species of the Bonin Islands, Japan, and cross-species amplification in closely related taxa. Conservation Genetics 8, 1487-1490.

Leimu, R., Mutikainen, P., Koricheva, J., Fischer, M., 2006: How general are positive relationships between plant population size, fitness and genetic variation? Journal of Ecology 94, 942952.

Liu, K., Muse, S. V., 2005: Power marker: an integrated analysis environment for genetic marker analysis. Bioinformatics 21, 2128-2129.

Luan, S. S., Chiang, T. S., Gong, X., 2006: High genetic diversity vs. low genetic differentiation in Nouelia insignis (Asteraceae), a narrowly distributed and endemic species in China, revealed by ISSR fingerprinting. Annals of Botany 98, 583-589.

Marcu, D., Cristea, V., Butiuc-Keul, A., 2006: Micropropagation of Dianthus pyrenaicus Pourr. - endemic species from Pyrenean Mountains. Contributii Botanice 41, 153-159.

Miclăuş, M., Cristea, V., Deliu, C., 2003: Micropropagation of Dianthus petraeus W. et K. simonkaianus (Péterfi) Tutin. Contributii Botanice 38, 77-84.

Oprea, A., 2005: Critical List of Vascular Plants from Romania, Editura Universitatii "Alexandru Ioan Cuza" Iaşi (in Romanian).

Otto, S. P., 2007: The evolutionary consequences of polyploidy. Cell 131, 452-462.

Paun, O., Forest, F., Fay, M. F., Chase, M. W., 2009: Hybrid speciation in angiosperms: parental divergence drives ploidy. New Phytologist 182, 507-518.

Peakall, R., Smouse, P. E., 2006: GENALEX 6: genetic analysis in Excel. Population genetic software for teaching and research. Molecular Ecology Notes 6, 288-295.

Peakall, R., Smouse, P. E., 2012: GenAlEx 6.5: genetic analysis in Excel. Population genetic software for teaching and research - an update. Bioinformatics 28, 2537-2539.

Pritchard, J. K., Stephens, M., Donnelly, P., 2000: Inference of population structure using multilocus genotype data. Genetics 155, 945-959.

Putz, C. M., Schmid, C., Reisch, C., 2015: Living in isolation population structure, reproduction, and genetic variation of the endangered plant species Dianthus gratianopolitanus (Cheddar pink). Ecology and Evolution 5, 3610-3621.
Reed, D. H., Frankham, R., 2003: Correlation between fitness and genetic diversity. Conservation Biology 17, 230-237.

Reisch, C., Schmidkonz, S., Meier, K., Schöpplein, Q., Meyer, C., Hums, C., Putz, C., Schmid, C., 2017: Genetic diversity of calcareous grassland plant species depends on historical landscape configuration. BMC Ecology 17.1, 19.

Saitou, N., Nei, M., 1987: The neighbor-joining method: A new method for reconstructing phylogenetic trees. Molecular Biology and Evolution 4, 406-425.

Sârbu, I., Ştefan, N., Oprea, A., 2013: Vascular Plants from Romania. Pictured determinator. Editura Victor B Victor, Bucureşti (in Romanian).

Soltis, P. S., Soltis, D. E., 2009: The role of hybridization in plant speciation. Annual Review of Plant Biology 60, 561-588.

Sosa, P. A., González-Pérez, M. A., Moreno, C., Clarke, J. B., 2010: Conservation genetics of the endangered endemic Sambucus palmensis Link (Sambucaceae) from the Canary Islands. Conservation Genetics 11, 2357-2368.

Smulders, M. J. M., Rus-Kortekaas, W., Vosman, B., 2000: Microsatellite markers useful throughout the genus Dianthus. Genome 43, 208-210.

Smulders, M. J. M., Noordijk, Y., Rus-Kortekaas, W., Bredemeijer, M., Vosman, B., 2003: Microsatellite genotyping of carnation varieties. Theoretical and Applied Genetics 106, 1191-1195.

Stöcklin, J., 1992: Differences in the location of subcotyledonary buds among Epilobium angustifolium L, E. dodonaei Vill and E. fleischeri Hochst (Onagraceae) and effects on architecture and population structure. Botanical Journal of Linnean Society $108,35-47$.

Szczecińska, M., Sramko, G., Wołosz, K., Sawicki, J., 2013: Genetic diversity and population structure of the rare and endangered plant species Pulsatilla patens (L.) Mill in East Central Europe, Plos One 11, e0151730.

Tamura, K., Stecher, G., Peterson, D., Filipski, A., Kumar, S., 2013, MEGA6: Molecular evolutionary genetics analysis version 6.0. Molecular Biology and Evolution 30, 2725-2729.

Valente, L. M., Savolainen, V., Vargas, P., 2010: Unparalleled rates of species diversification in Europe. Proceedings of Royal Society of London B: Biological Sciences 277, 1489-1496.

Varshney, R. K., Graner, A., Sorrells, M. E., 2005: Genic microsatellite markers in plants: features and applications. Trends in Biotechnolology 23, 48-55.

Young, A. G., Hill, J. H., Murray, B. G., Peakall, R., 2002: Breeding system, genetic diversity and clonal structure in the subalpine forb Rutidosis leiolepis F. Muell. (Asteraceae). Biological Conservation 106, 71-78.

Zietkiewicz, E., Rafalski, A., Labuda, D., 1994: Genome fingerprinting by simple sequence repeat (SSR)-anchored polymerase chain reaction amplification. Genomics 20, 176-183. 